\title{
Welfare and Environmental Implications of Farmed Sea Turtles
}

\author{
Phillip C. Arena · Clifford Warwick • \\ Catrina Steedman
}

Accepted: 21 August 2013/Published online: 27 September 2013

(C) The Author(s) 2013. This article is published with open access at Springerlink.com

\begin{abstract}
Various captivity-related health problems have been described as arising in the farming of sea turtles at the Cayman Turtle Farm (CTF). Our study included a desktop review of turtle farming, direct onsite inspection at the CTF, assessment of visual materials and reports provided by investigators from the World Society for the Protection of Animals (WSPA), and a limited analysis of water quality for potential pathogens. In particular, we assessed physical and behavioural condition of animals for signs of stress, injury and disease. During the onsite inspection we identified three distinct signs of physical injury and disease, six distinct signs of abnormal and problematic arousal- and discomfort-related behaviour; and three distinct signs of normal quiescence- and comfort-related behaviour. On evaluation of evidence provided by the WSPA we identified ten distinct signs of physical injury and disease, and managementor genetic-related conditions; six distinct signs of abnormal and problematic arousaland discomfort-related behaviour; and three distinct signs of normal quiescence- and comfort-related behaviour. We conclude that sea turtles at the CTF manifested important physical and behavioural signs that are indicative of problematic management and captivity-related stress, and the limitations of sea turtle adaptive plasticity in captivity. The problematic physical and behavioural signs, in our view, related to the inherent nature of intensive turtle propagation which in particular involves overt- and cryptoovercrowding and understimulating environments, and an associated failure to meet all the physical, biological and innate behavioural needs of sea turtles.
\end{abstract}

Keywords Sea turtles $\cdot$ Welfare $\cdot$ Stress $\cdot$ Disease $\cdot$ Injury $\cdot$ Cayman Turtle Farm

\section{P. C. Arena}

Murdoch University, Peel Campus, Education Drive, Mandurah, WA 6210, Australia

C. Warwick $(\bowtie) \cdot$ C. Steedman

Emergent Disease Foundation, Riverside House, River Lawn Road, Tonbridge, Kent TN9 1EP, UK e-mail: cliffordwarwick@yahoo.com 


\section{Introduction}

Despite a relatively long history of commercial interests in the farming of sea turtles, there exists little investigation of the welfare of these reptiles in captivity. The farming of sea turtles, as for the farming of other reptiles such as crocodiles, presents a suite of complex challenges for the provision of physical, physiological and behavioural needs. Where these needs are not satisfied, captivity-stress, morbidity and mortality may result (Arena and Warwick 2004; Warwick 2004; Warwick et al. 2013a). For example, the mortality of captive crocodiles has been explicitly linked to poor husbandry and rearing conditions (Huchzermeyer 2003). Furthermore, low metabolic rates in reptiles can mean that underlying disease and carrier status may long remain latent (Frye 1991). This symptomatic 'lag phase' from subclinical state to clinical presentation may enable pathogens to be shed and transmitted prior to disease detection and commencement of any treatment (Pare et al. 2006). This is not unique to any particular facility but a feature of turtle biology. Nevertheless, latent disease could be present in a turtle population that is then transferred to wild turtles via released specimens (Pare et al. 2006).

Green sea turtles (Chelonia mydas) are the most heavily exploited marine chelonian, and since 1968, this species has been raised commercially by the Cayman Turtle Farm (CTF) formerly 'Mariculture Ltd' (Reiser 2012). The Cayman Turtle Farm, located in the West Bay district of Grand Cayman, is the only large-scale sea turtle farm in existence and was purchased by the Cayman Island government in 1983. The CTF facility holds approximately 9,800 turtles (CTF FOI declaration to WSPA 2012), the vast majority of which are green sea turtles. In 2010, the facility reportedly produced 25,000 eggs of which just over 1,400 hatched (CTF promotional information 2011). The farm sells turtle meat exclusively on the island.

Various diseases have been described as arising in the farming of sea turtles and, in particular, in association with the CTF (Ariel 2011; Haines et al. 1974). As noted by Haines et al. (1974) in a commercial farming environment, when stress-loads are increased, not least by overcrowding, and conditions are not optimised for animal health, there is an associated high probability of disease and its transmission. In the 11 months between August 1990 and June 1991, a systemic infection of chlamydiosis swept through the CTF, killing hundreds of juvenile (4-5 year-old) green turtles. At the height of this epidemic, in August and September 1990, 10-30 turtles died each day (Homer et al. 1994). It may be presumed that where facilities necessarily involve the use of water such as the CTF, hygiene and pathogen transmission problems are easily exacerbated.

Such sources of contamination are not limited to the captive turtles. Public visitors to the CTF have general contact access to several turtle housing areas and turtle 'touch tanks'. Zoonotic (non-human animal-to-human) disease risks associated with the CTF were recently investigated and it was determined that farmed turtles may constitute a significant reservoir of potential human pathogen and toxin contamination (Warwick et al. 2013b). Furthermore, certain infections in turtles, for example herpesvirus, can remain indefinitely dormant and manifest acute onset disease triggered by stress (Hoff and Hoff 1984). It is also important to note that any facility 
that draws water from an external source such as the ocean, also risks introducing water that may be contaminated with pathogens shed by wild counterparts. Huchzermeyer (2002) similarly recognized that the practice of drawing water from lakes and rivers was a potential source of infection in crocodile farms. Given this, with regards to the CTF, there may also be some risk of disease transmission and spread from captive to wild turtle populations via the release of potentially contaminated wastewater, which is regularly discharged from the facility.

In 2002, a 2-week investigation by Godley gave the CTF a broadly positive review, noting that the operation is 'humane' and that, as with other intensive animal culture systems, some areas should be targeted for improvement. The report identified chronic skin conditions and the viral infection 'lung, eye and tracheal disease' as two major clinical entities within the CTF, and recommended improved quarantine and feeding strategies (Godley 2002).

According to a more recent 3 -week private investigation of the facility, some aspects of general management and husbandry are lax, including attention to turtle welfare and to the prevention and control of turtle diseases and husbandry and general hygiene issues. This investigation pointed out that many turtles appeared to be in good physical condition, but also noted that many individuals manifested signs of skin lesions, skin, limb, head and other injuries, probable systematic disease, and stress (WSPA unpublished).

Water quality is an obvious fundamental factor in the management of marine animals. According to Godley (2002) approximately 12.24 million gallons (approximately 57 million litres) of seawater per day was pumped through the CTF, and this basically exchanged resident volume 21 times each day. Smaller enclosures and those with animals undergoing (reportedly limited) quarantine or clinical treatment were additionally emptied and cleaned weekly, and also disinfected between batches of sea turtles. Observed declines in water quality (indicated by, for example, turbidity) were addressed via partial drainage and refilling (Godley 2002). Water throughput volume was reportedly considerable, in part to control the prevalence of skin disease in the turtles.

Numerous turtle ponds at the facility utilise shared water (WSPA unpublished), and the state of cleanliness of this water at all times was uncertain. According to the WSPA (unpublished) while some turtle tanks or ponds appeared visibly clean, others were heavily contaminated with turtle faeces and algae. If water-bearing enclosures are not cleaned regularly, uneaten food and voided faeces can quickly contaminate the living environment, resulting in a foul mix of water, debris and potentially pathogenic microorganisms, including bacteria and viruses (Frye 1991). Bacteria and fungi may rapidly multiply in the nutrient-rich, moist and warm environment of holding areas for turtles, and similar conditions have been recorded for captive crocodiles (Huchzermeyer 2003). The first author witnessed an outbreak of subcutaneous ulcerative disease in juvenile estuarine crocodiles (Crocodylus porosus) in an Australian crocodile farm (Fremantle-now closed) and attributed its occurrence and subsequent spread to poor husbandry and facility design because water from tanks housing infected individuals flowed to tanks that held previously non-infected individuals. Captivity-stress may also lead to a compromised immune system and result in turtles succumbing to otherwise 
innocuous microbes and other agents. Even high levels of immunity may be subjugated by overly contaminated water within intensive farming conditions (Huchzermeyer 2003).

Recently, in July 2012, it was reported that at the CTF, 299 turtles died as a result of a broken inlet pipe that fed seawater to the housing tanks (Anon 2012). Individual turtles were overcrowded and restrained in holding tanks without water and succumbed to hyperthermia. The current assessment investigates the welfare of sea turtles in captivity with a focus on the farming of marine turtles at the CTF.

\section{Methods}

Our investigation of the welfare of the captive sea turtle population at Cayman Turtle Farm (CTF) included an online literature search and review of relevant material, direct onsite inspection of the farm, and assessment of evidence gathered by investigators from the World Society for the Protection of Animals (WSPA).

For the online literature search for turtle farming-related issues the following key terms were used: 'Chelonia mydas' 'turtle', 'sea', 'marine', 'commerc', 'ranch', 'breed', 'farm', 'welfare', 'behaviour', 'behavior', 'disease'. Fifty-two publications of prima facie relevance were identified and reviewed, of which 15 articles and reports were determined to be cogent.

For our onsite inspection, data were collated by first counting all visible turtles by class (for example, 'adult breeder', 'juvenile/medium', and 'dinner-plate-size') in the display enclosures to estimate the relevant population size, then recording each relevant sign among a 'manageable visual field' of turtles (which was essentially smaller than the total number of turtles in each class), and then recording the number of animals showing relevant signs of captivity-stress related injuries, disease and behavioural problems. We also looked for signs of quiescence and comfort. Visible turtles constituted either the substantial majority or all turtles in the 'juvenile/ medium', and 'dinner-plate-size' classes. Where the 'adult breeders' were concerned, visible turtles possibly constituted approximately 20-30\% of that class, assuming historical estimates for the population of this turtle class (range from $>300$ to 500 individuals, the WSPA unpublished) are correct. Regardless, all onsite counts were significantly representative of turtle populations. The onsite inspection at the CTF consisted of approximately $550 \mathrm{~min}$ of direct observation of animals. A comparison of results was made using 15 versus 5 min observation periods for one sign of prevalence for physical condition (neck lesions) and one sign of prevalence for behavioural condition (co-occupant aggression) and both observation periods produced almost identical results. Accordingly, the 5-min observation period was used per enclosure and for each assessment task. Annotation and high-resolution digital imaging recorded observations and evidence.

We are confident that within the display areas, our counts represented almost all of the turtles in the 'juvenile/medium' and 'dinner-plate' classes. Where the 'adult breeder' class was concerned, no more than 103 animals were seen, despite the claims of there being far greater numbers ( $>300-500)$. Nevertheless, we have taken the farm's claims regarding the adult breeder population prima facie. Our direct 
onsite observations relate to 338 animals and 46-63\% (depending on the prima facie number of adult breeders) of all livestock in the display areas. All our observations were carried out in open public places.

We also examined visual materials and reports provided by investigators from the WSPA, which consisted of approximately $180 \mathrm{~min}$ high resolution digital video and 405 still digital images of turtle physical condition and behaviour, and extensive independent (WSPA) investigators' notes. Evidence provided by the WSPA involved both the display and production areas of the CTF. Target signs were either counted from the entire image-visible population or, where large numbers of turtles were represented in images, we used overlaid digital grids to count and estimate both type and frequency of relevant signs. Because total numbers of turtles could not always be counted from the WSPA digital material, we elected to represent prevalence as 'Rare' $=1-5 \%$; 'Occasional' $=>5-20 \%$; $\quad$ 'Frequent' $=>20-35 \%$; $\quad$ 'Common' $=>35-50 \%$; 'Extremely common' $=>50 \%$. This 'subjective' analysis broadly corresponded with the onsite inspection, in that both methods used main groups of visible populations from which manageable subgroups of animals were identified for observation. Our assessment of the WSPA evidence relates to $>420$ animals and approximately $5 \%$ of all livestock in the main production section of the facility.

Assessments of physical and behavioural condition of animals targeting signs of injury, disease, stress, and good health as presented in, for example, Glazebrook and Campbell (1990), Norton (2005a, b), Arena and Warwick (2004), Warwick (2004), and Warwick et al. (2013a), were conducted using non-invasive observation. Lesions and diseases were provisionally identified and subsequently confirmed by a senior specialist in reptile veterinary pathology and husbandry. In addition, farm water quality was also tested for the presence of potentially pathogenic agents. Water samples were analysed independently by Greendale Laboratories, Woking, UK.

Data for both the number of actual injuries and problematic behaviour episodes could not be obtained for all animals, even from onsite inspection, due to the tendency for some turtles to submerge or reside out of sight. Whilst we were able to obtain good representative sampling for each target sign, the near constant movement of turtles precluded the formation of estimates for overlapping signs and we could not determine the prevalence or otherwise of shared signs.

\section{Results}

\section{Onsite Inspection}

During the onsite inspection we identified three distinct signs of physical injury and disease, six distinct signs of abnormal and problematic arousal- and discomfortrelated behaviour, and three distinct signs of normal quiescence- and comfortrelated behaviour (Tables 1-3).

\section{Physical considerations}




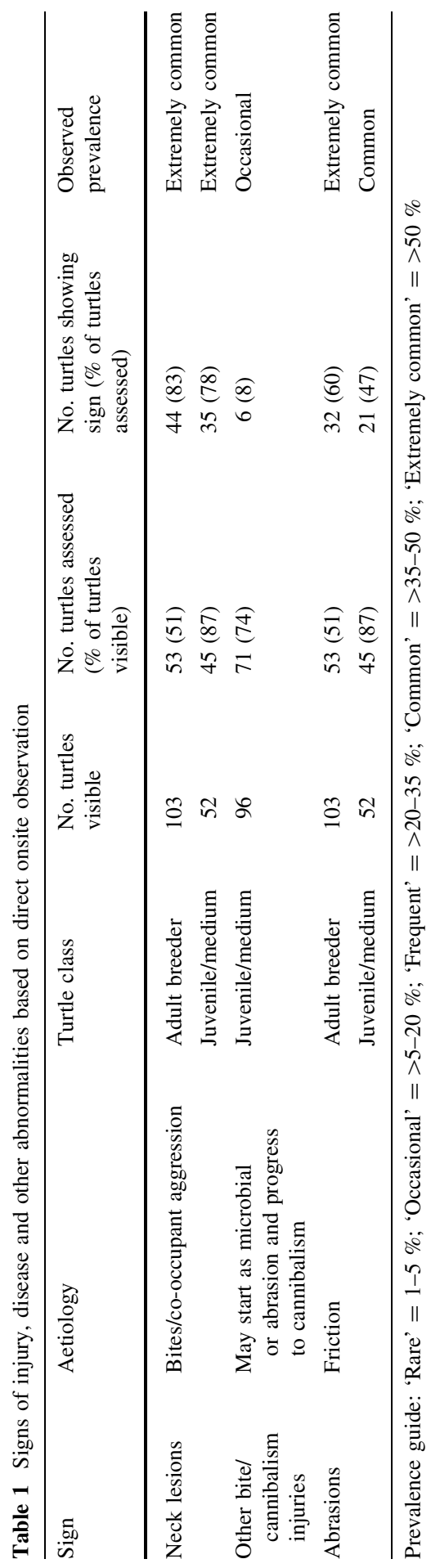




\section{Behavioural considerations}

Handling of turtles associated with the 'touch tanks' typically involved the smaller 'dinner-plate' sized animals. Of the 84 observed turtle handlings, 77 animals displayed stress-related responses, which were escape and flight reactions (flailing while in hands and rapidly swimming away underwater) and immediate posthandling antipredator posturing (flippers tucked, head down) (Gillingham 2004;

Table 2 Signs of negative behavioural and psychological arousal and discomfort (stress) in captive sea turtles based on direct onsite observation

\begin{tabular}{|c|c|c|c|c|c|c|}
\hline Sign & $\begin{array}{l}\text { Aetiology/ } \\
\text { summary } \\
\text { key }\end{array}$ & $\begin{array}{l}\text { Turtle } \\
\text { class }\end{array}$ & $\begin{array}{l}\text { No. } \\
\text { turtles } \\
\text { visible }\end{array}$ & $\begin{array}{l}\text { No. turtles } \\
\text { assessed ( } \% \\
\text { of turtles } \\
\text { visible) }\end{array}$ & $\begin{array}{l}\text { No. turtles } \\
\text { showing sign } \\
\text { (\% of turtles } \\
\text { assessed) }\end{array}$ & $\begin{array}{l}\text { Observed } \\
\text { prevalence }\end{array}$ \\
\hline $\begin{array}{l}\text { Hyperactivity } \\
\text { (abnormal high- } \\
\text { level physical } \\
\text { activity, surplus or } \\
\text { redundant activity) }\end{array}$ & $1,2,3,7$ & $\begin{array}{l}\text { Juvenile/ } \\
\text { medium }\end{array}$ & 104 & 49 (47) & $6(12)$ & Occasional \\
\hline $\begin{array}{l}\text { Rapid body } \\
\text { movement } \\
\text { (abnormal 'jerky' } \\
\text { locomotor or } \\
\text { 'panicked' activity) }\end{array}$ & $1,2,4,5$ & $\begin{array}{l}\text { Juvenile/ } \\
\text { medium }\end{array}$ & 92 & $44(48)$ & $3(7)$ & Occasional \\
\hline \multirow{2}{*}{$\begin{array}{l}\text { Boundary exploration } \\
\text { (persistent } \\
\text { swimming against } \\
\text { or tracking } \\
\text { boundary) }\end{array}$} & \multirow[t]{2}{*}{$1,2,3,7$} & $\begin{array}{l}\text { Adult } \\
\text { breeders }\end{array}$ & 102 & $56(55)$ & $21(38)$ & Common \\
\hline & & $\begin{array}{l}\text { Juvenile/ } \\
\text { medium }\end{array}$ & 112 & $51(46)$ & $43(84)$ & $\begin{array}{r}\text { Extremely } \\
\text { common }\end{array}$ \\
\hline \multirow{2}{*}{$\begin{array}{l}\text { Surface congregation } \\
\text { (animals grouping } \\
\text { together at the water } \\
\text { surface) }\end{array}$} & \multirow[t]{2}{*}{$\begin{array}{c}1,2,3,6 \\
7\end{array}$} & $\begin{array}{l}\text { Juvenile/ } \\
\text { medium }\end{array}$ & 94 & $41(44)$ & $12(29)$ & Frequent \\
\hline & & $\begin{array}{c}\text { Dinner- } \\
\text { plate }\end{array}$ & 121 & 35 (29) & $5(14)$ & Occasional \\
\hline $\begin{array}{l}\text { Apprehension } \\
\text { (animals avoid } \\
\text { approaches from } \\
\text { conspecifics) }\end{array}$ & $1,2,3,7$ & $\begin{array}{c}\text { Dinner- } \\
\text { plate }\end{array}$ & 123 & $123(100)$ & $25(20)$ & Occasional \\
\hline \multirow{3}{*}{$\begin{array}{l}\text { Aggression and } \\
\text { cannibalism (co- } \\
\text { occupant biting and } \\
\text { attacks, partial } \\
\text { consumption of } \\
\text { cage-mates) }\end{array}$} & \multirow[t]{3}{*}{$1,2,3,7$} & $\begin{array}{l}\text { Adult } \\
\text { breeders }\end{array}$ & 98 & $33(34)$ & $7(21)$ & Common \\
\hline & & $\begin{array}{l}\text { Juvenile/ } \\
\text { medium }\end{array}$ & 105 & $55(52)$ & $12(22)$ & Frequent \\
\hline & & $\begin{array}{l}\text { Dinner- } \\
\text { plate }\end{array}$ & 115 & 45 (39) & $8(18)$ & Occasional \\
\hline
\end{tabular}

Aetiology/summary keys: $1=$ Stress, $2=$ Overcrowding, $3=$ Overly restrictive, deficient and inappropriate environments, $4=$ Often related to fear, defence and escape behaviour, $5=$ Exposed, deficient and inappropriate environments, $6=$ Hunger, $7=$ Self-compounding and destructive

Prevalence guide: 'Rare' $=1-5 \%$; 'Occasional' $=>5-20 \%$; 'Frequent' $=>20-35 \%$; 'Common' $=>35-50 \%$; 'Extremely common' $=>50 \%$ 
Table 3 Signs of positive behavioural and psychological quiescence and comfort in captive sea turtles based on direct onsite observation and the WSPA evidence

\begin{tabular}{|c|c|c|c|}
\hline Behaviour & Signs & Aetiology & Frequency \\
\hline $\begin{array}{l}\text { Quiescent exploratory } \\
\text { behaviour }\end{array}$ & $\begin{array}{l}\text { Passive environmental boundary } \\
\text { exploration }\end{array}$ & $\begin{array}{l}\text { Normal environmental } \\
\text { exploration }\end{array}$ & Occasional \\
\hline $\begin{array}{l}\text { Quiescent exploratory } \\
\text { behaviour }\end{array}$ & $\begin{array}{l}\text { General (non-boundary) } \\
\text { environmental exploration }\end{array}$ & $\begin{array}{l}\text { Normal environmental } \\
\text { exploration }\end{array}$ & Occasional \\
\hline Quiescent feeding & Relaxed (normal) feeding & Normal grazing activity & Occasional \\
\hline
\end{tabular}

Prevalence guide: 'Rare' $=1-5 \% ; \quad$ 'Occasional' $=>5-20 \% ; \quad$ 'Frequent' $=>20-35 \%$; 'Common' $=>35-50 \%$; 'Extremely common' $=>50 \%$

Mellgren and Mann 2003; Smith and Salmon 2009), and 7 displayed no stressrelated response.

As a supplementary exercise, observations were also conducted regarding the physical condition and behaviour of six dinner-plate class turtles that occupied the large 'lagoon' - which is a naturalistic marine environment substantially larger than other environments within the facility.

\section{Examination of WSPA Evidence}

\section{Physical Considerations}

Evaluation of evidence provided by the WSPA revealed 10 distinct categories of physical injury and disease, and management- or genetic-related conditions

Table 4 Signs of injury, disease and other abnormalities based on the WSPA's digitally recorded images

\begin{tabular}{lll}
\hline Signs & Aetiology & $\begin{array}{l}\text { Observed } \\
\text { prevalence }\end{array}$ \\
\hline $\begin{array}{ll}\text { Degenerative shell lesions } \\
\text { Microbial infection lesions }\end{array}$ & Hypertrophic algal formation & Common \\
Microbial ulceration & Bacterial/fungal/viral disease? & Common \\
Abrasions & Bacterial/fungal disease? & Occasional \\
Ocular injury and disease & Friction & Common \\
Tissue necrosis & Bacterial/fungal/viral disease? & Common \\
Developmental anomalies including & Genetic or incubation related condition & Frequent \\
no or diminutive eyes & Bacterial/fungal/viral disease? & Rare \\
Floating & Bacterial/fungal/viral disease? & Occasional \\
Cannibalism injuries & Bacterial/fungal/viral disease? & Occasional \\
& May start as a microbial or abrasion lesion and & Frequent
\end{tabular}

Prevalence guide: 'Rare' $=1-5 \%$; 'Occasional' $=>5-20 \% ; \quad$ 'Frequent' $=>20-35 \%$; 'Common' $=>35-50 \%$; 'Extremely common' $=>50 \%$ 


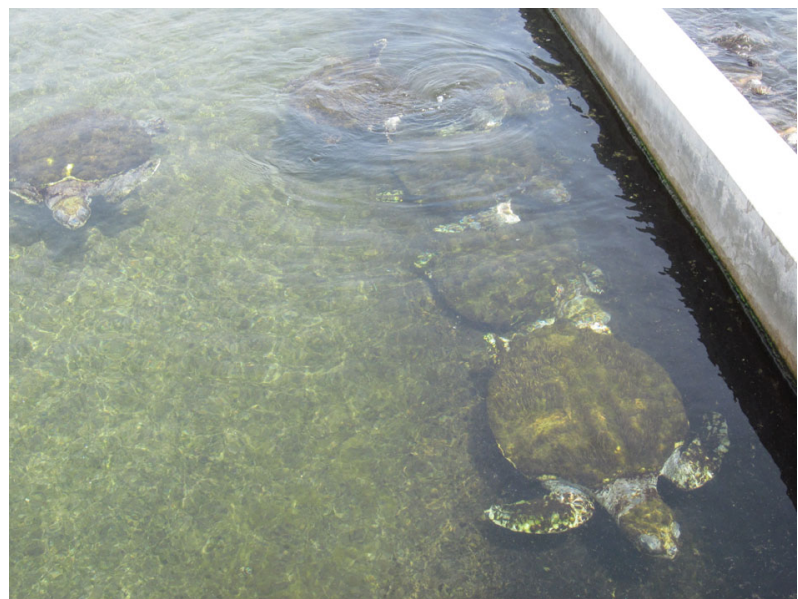

Fig. 1 Green turtles (Chelonia mydas), each with multiple bite wounds and showing hypertrophic algal formation in algal growth. Photo WSPA

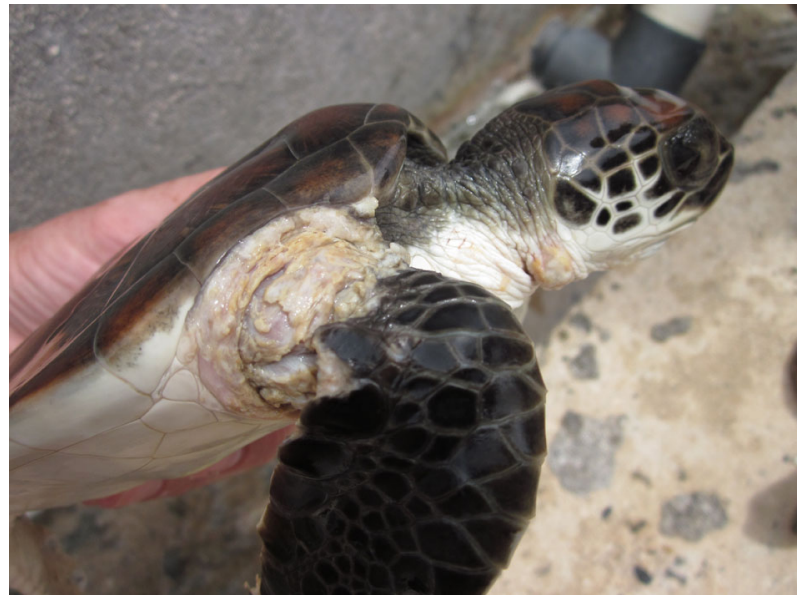

Fig. 2 Chronic dermatitis and at least one lesion that appears to be 'grey-patch' disease (herpesviral dermatitis of marine turtles, in particular, Chelonia mydas). Photo WSPA

(Table 4). The type and range of physical problems was extensive and included relatively mild but important issues (such as hypertrophic algal formation) through to severe injury, blindness and skeletal defects from management or genetic factors. Hypertrophic algal formations were commonly present on the shells and limbs of turtles (Fig. 1). Chronic dermatitis and apparent 'grey-patch' disease were, likewise, 


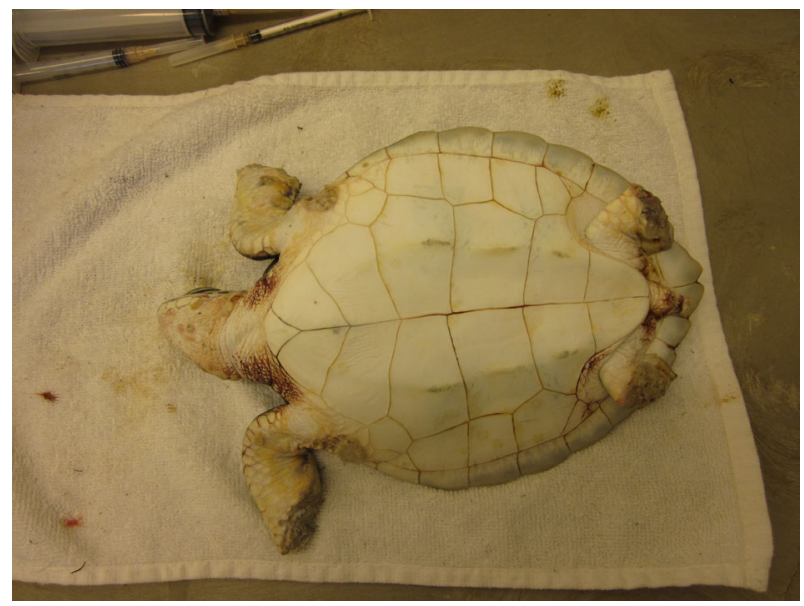

Fig. 3 Turtle (Chelonia mydas) in dorsal recumbency with quadrilateral massive and infected bite wounds to each of its flippers; a fresh-appearing wound involving its tail. Photo WSPA

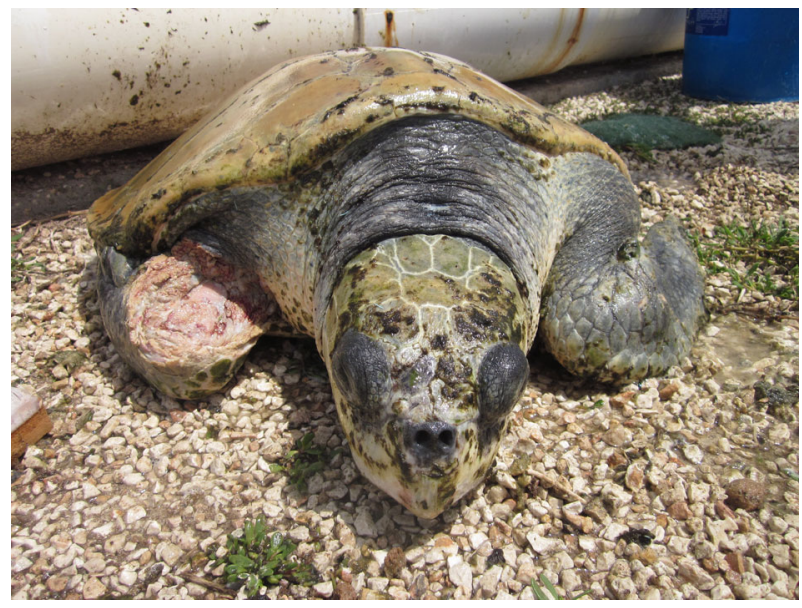

Fig. 4 Kemps ridley turtle (Lepidochelys kempii). Massive bite wound to the dorsal surface of the right foreflipper. Photo WSPA

commonly noted (Fig. 2). Many turtles, particularly juveniles, manifested major injuries, particularly to their soft tissues, including missing limbs (Figs. 3, 4). Some juveniles had lost all four limbs, others, for example hatchlings, were seen floating unresponsive in the hatchling tank. Management- (for example, poor incubation) or genetic-related defects were occasionally observed (Fig. 5). 
Fig. 5 Green turtle (Chelonia mydas) with developmental defect which includes bilateral anophthalmia. Photo WSPA

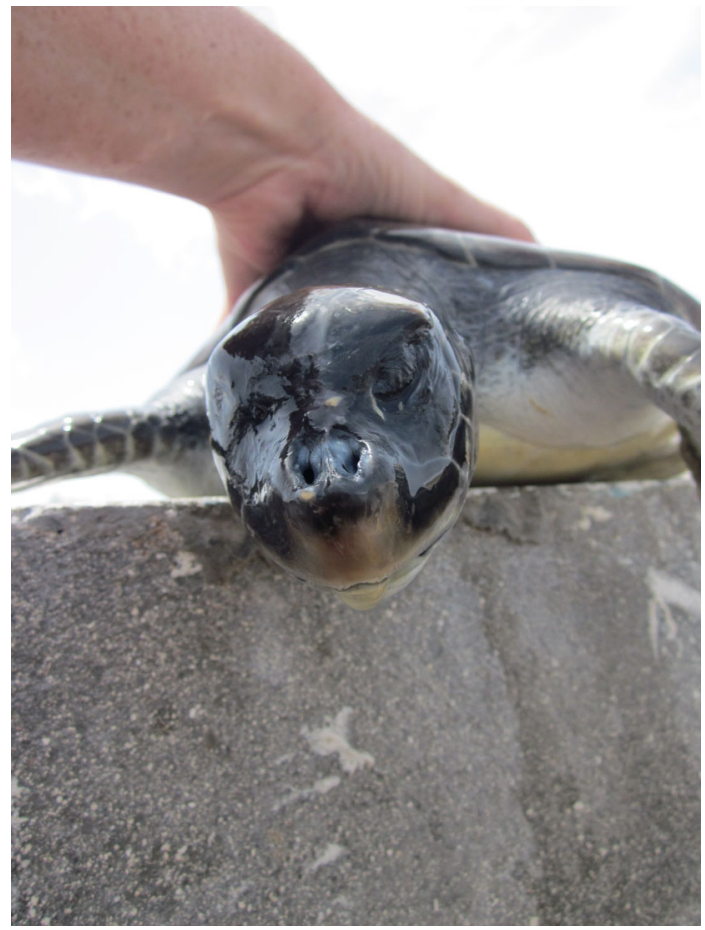

\section{Behavioural Considerations}

Evaluation of evidence provided by the WSPA identified six distinct signs of abnormal and problematic arousal- and discomfort-related behaviour (Table 5) and three distinct signs of normal quiescence- and comfort-related behaviour (Table 3).

Signs of arousal and discomfort were more commonly observed in all enclosures (Fig. 6). Signs of quiescence and comfort were occasionally observed in the larger, less densely populated, adult 'breeder' lake. However, this class also manifested

Table 5 Signs of negative behavioural and psychological arousal and discomfort (stress) in captive sea turtles based on the WSPA's digitally recorded images

\begin{tabular}{llll}
\hline Behaviour & Signs & Aetiology & $\begin{array}{c}\text { Observed } \\
\text { prevalence }\end{array}$ \\
\hline Hyperactivity & $\begin{array}{c}\text { Abnormal high-level } \\
\text { physical activity, surplus } \\
\text { or redundant activity }\end{array}$ & $\begin{array}{c}\text { Stress. Overcrowding self-compounding } \\
\text { and destructive. Overly restrictive, } \\
\text { deficient and inappropriate } \\
\text { environments. }\end{array}$ & Common \\
$\begin{array}{c}\text { Rapid body } \\
\text { movement/ } \\
\text { escape }\end{array}$ & $\begin{array}{c}\text { Abnormal 'jerky' locomotor } \\
\text { or 'panicked' activity }\end{array}$ & $\begin{array}{l}\text { Stress often related to fear, defence and } \\
\text { escape behaviour, common in overly } \\
\text { restrictive, and exposed, deficient and } \\
\text { inappropriate environments. }\end{array}$ & Occasional \\
\hline
\end{tabular}


Table 5 continued

\begin{tabular}{|c|c|c|c|}
\hline Behaviour & Signs & Aetiology & $\begin{array}{l}\text { Observed } \\
\text { prevalence }\end{array}$ \\
\hline $\begin{array}{l}\text { Boundary } \\
\text { exploration }\end{array}$ & $\begin{array}{l}\text { Persistent swimming against } \\
\text { or tracking boundary }\end{array}$ & $\begin{array}{l}\text { Stress. Overcrowding self-compounding } \\
\text { and destructive. Overly restrictive, } \\
\text { deficient and inappropriate environments }\end{array}$ & Common \\
\hline $\begin{array}{l}\text { Surface } \\
\text { congregation }\end{array}$ & $\begin{array}{l}\text { Animals grouping together } \\
\text { at the water surface }\end{array}$ & $\begin{array}{l}\text { Stress. Overcrowding self-compounding } \\
\text { and destructive. Overly restrictive, } \\
\text { deficient and inappropriate } \\
\text { environments, hunger }\end{array}$ & Frequent \\
\hline $\begin{array}{l}\text { Frenzied } \\
\text { feeding }\end{array}$ & $\begin{array}{l}\text { Animals engage in highly } \\
\text { competitive feeding } \\
\text { clusters }\end{array}$ & $\begin{array}{l}\text { Stress. Overcrowding self-compounding } \\
\text { and destructive. Overly restrictive, } \\
\text { deficient and inappropriate } \\
\text { environments, hunger }\end{array}$ & Frequent \\
\hline Cannibalism & $\begin{array}{l}\text { Co-occupant biting and } \\
\text { attacks, partial } \\
\text { consumption of cage- } \\
\text { mates }\end{array}$ & $\begin{array}{l}\text { Stress. Overcrowding self-compounding } \\
\text { and destructive. Overly restrictive, } \\
\text { deficient and inappropriate } \\
\text { environments, hunger }\end{array}$ & Common \\
\hline
\end{tabular}

Prevalence guide: 'Rare' $=1-5 \%$; 'Occasional' $=>5-20 \% ; \quad$ 'Frequent' $=>20-35 \%$; 'Common' $=>35-50 \%$; 'Extremely common' $=>50 \%$

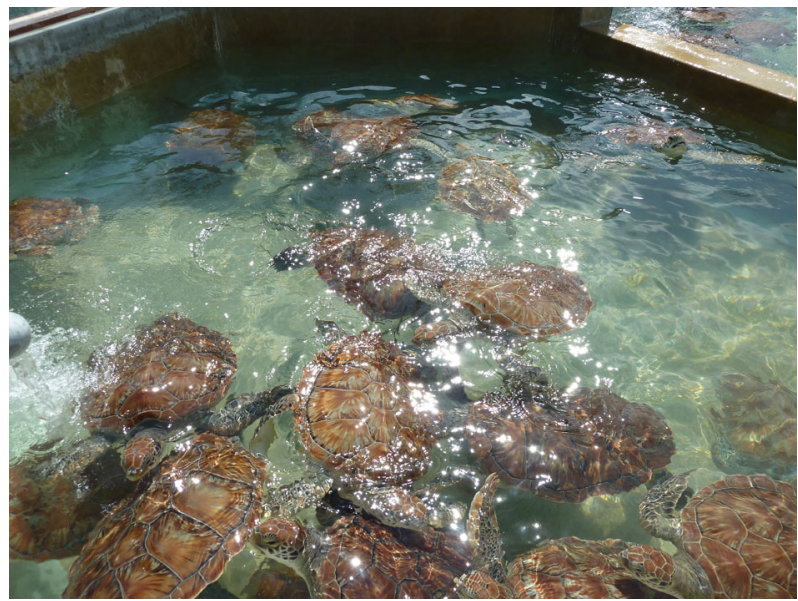

Fig. 6 Green turtles (Chelonia mydas) in densely populated ponds common showed signs of captivity stress including hyperactivity, boundary exploration and co-occupant aggression. Photo WSPA

significant signs of arousal and discomfort (particularly competition-stress and cooccupant aggression) in addition to incidental forceful and injurious contact during feeding sessions where 'frenzies' frequently occurred (Fig. 7). 


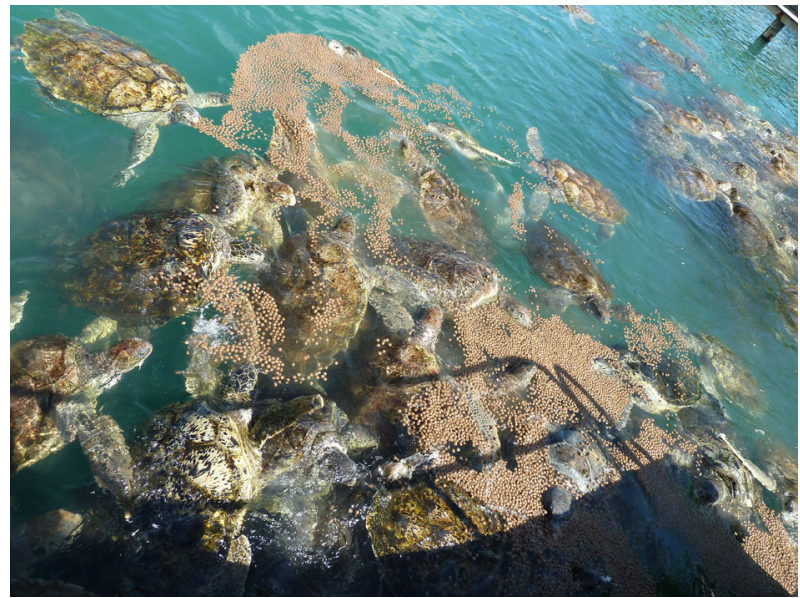

Fig. 7 Green turtles (Chelonia mydas) in 'breeder' lakes manifested signs of captivity-stress in particular competition-stress and co-occupant aggression during feeding frenzies. Photo WSPA

\section{Water sampling}

Results of water sampling for bacteria are presented in Table 6.

Table 6 Microbiological analysis of water samples from turtle enclosures at the CTF

\begin{tabular}{|c|c|c|c|}
\hline Sample no. & Source & Bacteria isolated & Potentially pathogenic to turtles/humans \\
\hline 1 & Outflow pipe & Negative & - \\
\hline 2 & Outflow pipe & Negative & - \\
\hline 3 & Touch tank & Aeromonas sp. & Turtles/humans \\
\hline 4 & Turtle tank & Negative & - \\
\hline 5 & Turtle tank & Negative & - \\
\hline 6 & Touch tank & Pseudomonas aeruginosa & Turtles/humans \\
\hline 7 & Touch tank & Negative & - \\
\hline 8 & Adult tank & Negative & - \\
\hline 9 & Adult tank & Aeromonas sp. & Turtles/humans \\
\hline \multirow[t]{2}{*}{10} & Juvenile tank & Vibrio sp. & Turtles/humans \\
\hline & & Salmonella sp. & Turtles/humans \\
\hline 11 & Lagoon & Vibrio sp. & Turtles/humans \\
\hline 12 & Outflow pipe & Negative & - \\
\hline 13 & Outflow pipe & Negative & - \\
\hline \multirow[t]{2}{*}{14} & Turtle tank & Escherichia coli & Turtles/humans \\
\hline & & Enterococcus sp. & Turtles/humans \\
\hline 15 & Lagoon & Negative & - \\
\hline 16 & Turtle tank & Enterococcus sp. & Turtles/humans \\
\hline \multirow[t]{2}{*}{17} & Lagoon & Vibrio alginolyticus & Turtles/humans \\
\hline & & Aeromonas hydrophila & \\
\hline 18 & Lagoon & Aeromonas hydrophila & Turtles/humans \\
\hline
\end{tabular}


Table 6 continued

\begin{tabular}{llll}
\hline Sample no. & Source & Bacteria isolated & Potentially pathogenic to turtles/humans \\
\hline 19 & Touch tank & Vibrio vilnificus & Humans \\
20 & Turtle tank & Vibrio alginolyticu & Turtles/humans \\
& & Vibrio vulnificus & Humans \\
21 & Touch tank & Escherichia coli & Turtles/humans \\
& & Enterococcus sp. & Turtles/humans \\
22 & Turtle tank & Vibrio alginolyticus & Turtles/humans \\
& & Shewanella putrefaciens & Turtles/humans \\
23 & Lagoon & Vibrio alginolyticus & Turtles/humans \\
& & Vibrio vilnificus & Humans \\
24 & Turtle tank & Escherichia coli & Turtles/humans \\
& & Streptococcus sp. & Turtles/humans \\
25 & Touch tanks & Moraxella sp. & Turtles/humans \\
26 & Main tanks & Vibrio vulnificus & Humans \\
& Main tanks & Salmonella sp. & Turtles/humans \\
& & Escherichia coli & Turtles/humans \\
& & Enterococcus spp. & Turtles/humans \\
\hline & & &
\end{tabular}

Outflow pipe = water taken from a pipe that expels water from the Cayman Turtle Farm; Touch tank = turtle enclosures where tourists are actively encouraged to handle turtles; Turtle tank = general enclosure; Adult tank = turtle tanks where tourists can touch turtles unsupervised; Juvenile tank = general enclosure; Lagoon $=$ area where tourists can swim with turtles; Main tanks = general enclosures

\section{Discussion}

Our assessment of the CTF involved both objective observation as well as limited subjective observation where the WSPA's evidence was being assessed. Where standard observations could not be made, subjective assessments of animal welfare were used and found to correlate well with objective assessments (for example for evaluating stress in food animals from stress-related vocalisations) (Warriss et al. 1994). We felt that our dual approach using both objective and subjective assessments (both of which involved objective evaluation) reasonably represents conditions and issues of animal welfare at the CTF.

Although we established two distinct categories of primary consideration, 'physical' and 'behavioural', it should be noted that there was often considerable overlap between these scenarios. For example, physical injuries from bites, which may then additionally result in infections, were frequently causally related to feeding frenzies (due largely to overcrowding) and co-occupant aggression. Underlying management failures promulgated these scenarios (for example, stocking densities and spatial provisions, feeding regimens, and poor water quality).

\section{Physical Considerations}

Certain management- and behaviour-related problems led to physical injuries and in turn, these can invite potential infection and disease. The Cayman Turtle Farm 


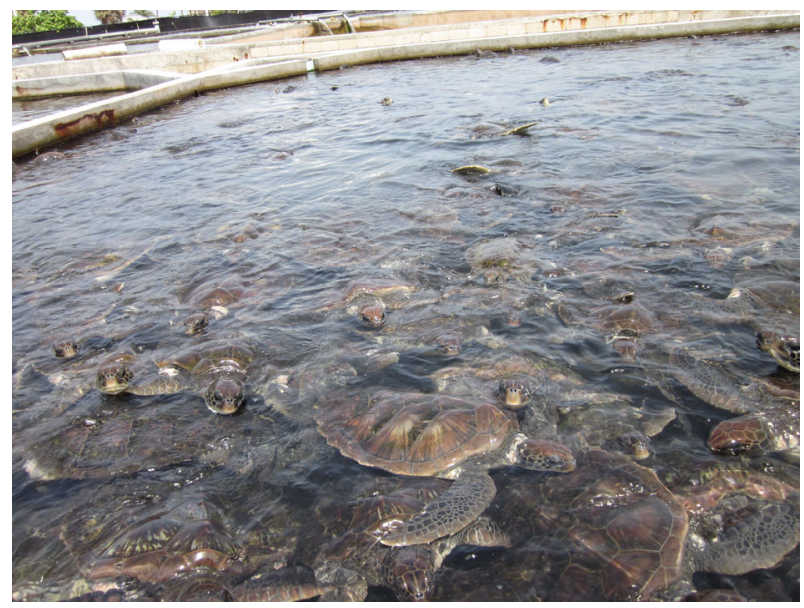

Fig. 8 Overt-overcrowding in one of the main production ponds off-public view. Photo WSPA

incorporates both multiple-occupation ponds in addition to interconnected ponds using shared water systems. This questionable arrangement includes introduced direct risk of cross-contamination of potentially pathogenic microbes and macroparasites to many animals and represented a persistent and enduring animal health risk.

Under natural conditions, marine algae may establish and grow in patches on sea turtle shells and provide incidental food for symbiotes such as fishes that predate on ectoparasites (Losey et al. 1994; Sazima et al. 2010). However, in the absence of symbiotic grazer species and the presence of certain concomitant environmental and immune scenarios, such algae growth is capable of degrading keratinised shell layers and result in significant morbidity among farmed turtles. Furthermore, the presence of dense mats of algae serves to mask other potentially problematic issues, most specifically, signs of injury and disease.

In our view, overcrowding affected all turtles in all ponds. In some enclosures, for example the commercial production ponds, as distinct from the display ponds, overcrowding may have appeared obvious (Fig. 8). In others, for example the display and in particular the breeder lake, the presence of larger bodies of water and artificial beaches prima facie appeared 'spacious'. However, overcrowding can be considered as having two 'forms': 'overt overcrowding' and 'covert (or 'crypto') overcrowding'. Overt overcrowding may be estimated by the number of animals occupying a certain amount of space, whereas crypto overcrowding essentially refers to the accessibility of all facilities to which all animals have free access whenever required (Warwick et al. 2011a, b). Accordingly, an enclosure that appeared large and abundant but that lacked the ability to provide for the needs of all the animals at any time was capable of being overcrowded. By this measure, all facilities throughout the CTF were subject to overt or crypto overcrowding. Marine turtles are coastal- and oceanic-going animals that, like all reptiles, possess hard-wired traits, which typically includes extensive home ranges (Warwick 1990; Warwick et al. 2013a).

Numerous individual turtles were affected either by managemental (for example, poor incubation) or genetically related birth defects. These included anophthalmia 
blindness (congenital absence of one or both eyes) and marked skeletal deformities (particularly of the cranium).

Ross (1999) commented that questions of sea turtle maintenance and husbandry have only indirect application to wild turtle conservation. However, we consider that the release of the CTF turtles to the wild as well as discharged farm water into the sea includes the potential risk of disseminating both farm-present pathogens and biologically unfit or carrier-state animals to natural turtle populations and the wider environment.

Godley (2002) described turtle farming as no different from other animal farming for consumption. We would agree that in some respects this is a reasonable assumption. However, key differences do exist between sea turtle and other animal (for example, cattle) husbandry. Cattle have been domesticated for a period of at least 5,000 years and possess particular pre-adaptive traits that lend these animals to human-environment sharing. Turtles are reptiles and possess strong innate drive states evolved within a naturally spacious and diverse oceanic environment. Accordingly, the animal welfare implications for turtles in a captive lifestyle associated with human control warrant different considerations from other farmed animals. In brief, it is our view that sea turtle farming involves greater captivitystress for these animals than cattle farming imposes on those animals. Additionally, it needs to be emphasized that, unlike cattle, all species of sea turtle are endangered species and as such "should not have to earn their survival through commercialization" (Ehrinfield, as cited in Reiser 2012, pp. 122-123).

Dorsal aspect neck lesions (Fig. 9) were extremely common in the adult breeder population, and other injuries, for example, to the tail were occasionally observed (Fig. 10). The turtles frequently bite each other in the neck region during competition for food and other co-occupant harassment episodes (Fig. 11). This 'breeder' population is a long-term feature of the farm and thus more 'mature' these turtles have more time than others in which to accumulate injuries and compounding factors.

A recent (2012) CTF-sponsored investigation of the farm reported the following issues: concern at the incidence of skin lesions and early juvenile mortality levels; a

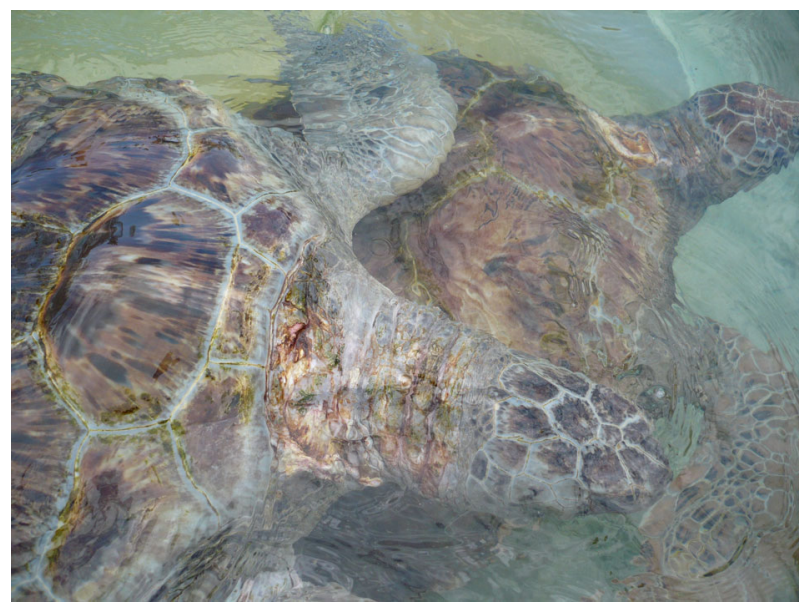

Fig. 9 Dorsal neck lesion from bite injuries. Photo C Warwick 


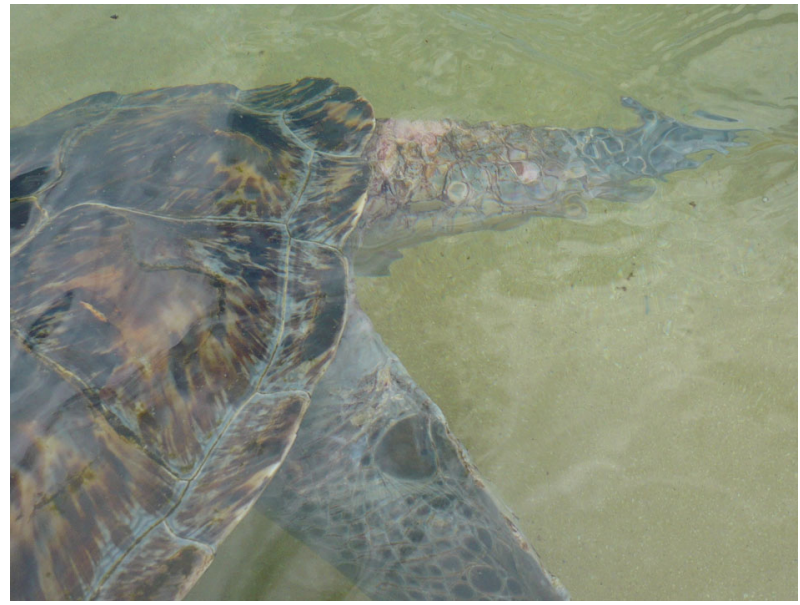

Fig. 10 Tail lesion from bite injury. Photo C Warwick

Fig. 11 Co-occupant

aggression in juvenile. Photo $\mathrm{C}$ Warwick

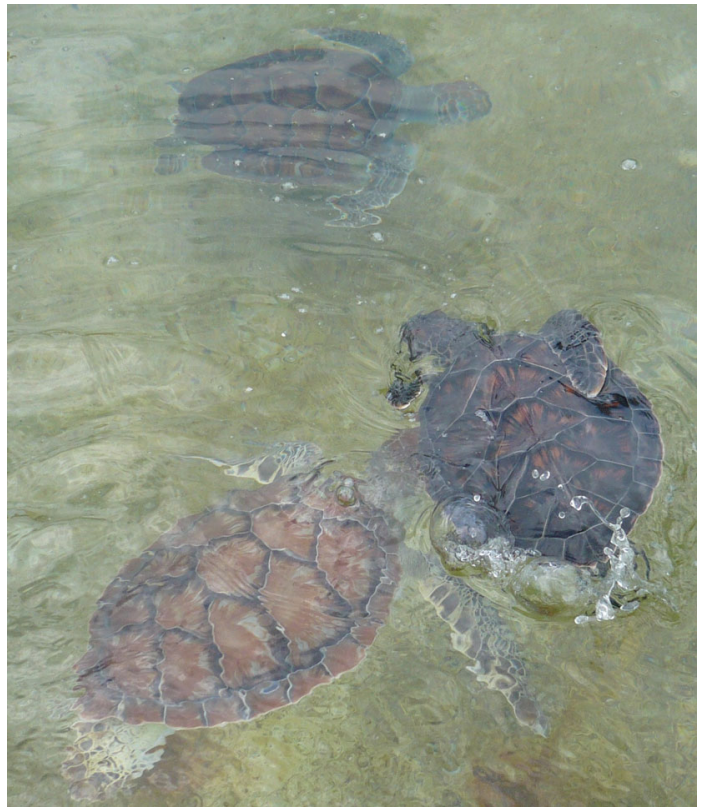

notable proportion of severe skin lesions including deep ulceration to the shoulder, forelimbs, head and hind limbs; high mortality levels in younger classes; potentially emerging enteritis conditions; and a notable apparent proportion of moderately emaciated animals (Balazs et al. unpublished). Those findings further confirm aspects of our assessment of the WSPA (unpublished) evidence regarding ongoing presence of important disease at the facility. The CTF itself reports mortality-rates during the years $2007-2011$ at: $2007=4.4 \% ; 2008=5.4 \% ; 2009=7.2 \%$; $2010=4.9 \%$; and $2011=8.1 \%$ (CTF FOI declaration to WSPA 2012). 
It is unclear whether or to what extent the CTF farm water that is subsequently returned to the sea may harbour actively pathogenic or environmentally destructive agents. It is known that diseases in sea turtles, for example lung, eye and tracheal disease, grey-patch disease and fibropapillomatosis, all constitute potential infectious pathogens and have all been reported from the CTF (Godley 2002). These diseases involve herpesviruses and are capable of remaining in an infective state in seawater for up to $120 \mathrm{~h}$ (Curry et al. 2000). Glazebrook and Campbell (1990) provided a list of bacterial diseases of farmed green turtles (Chelonia mydas) and hawksbill turtles (Eretmochelys imbricata), which included the following pathogens: Vibrio alginolyticus; Aeromonas hydrophila; Pseudomonas fluorescens; P. aeruginosa; Cytophaga-Flavo-bacterium sp.; Mycobacterium sp.; Salmonella enteritidis; Escherichia coli H2S+ve, Arizona hinshairi; and Streptococcus sp. Norton (2005a) cites Enterococcus sp. as being common in some Kemp's ridley turtles (Lepidochelys kempii). Water samples obtained for the present study (presented in Table 6) demonstrated the ongoing presence of these and other important turtle-pathogenic bacteria (several of which are also zoonotic) even from these limited tests.

In addition to potentially 'contaminated' water impacting on wild populations of turtles, this source of possible infection may also find its way back into the facility, exacerbate the general contaminant load, and threaten the health of all captive individuals, regardless of level of immunity.

\section{Behavioural Considerations}

Problematic behaviours indicated maladaptation and captivity-stress. At the most basic level, common problematic issues included unsuccessful attempts by turtles to bask and thus precisely regulate physiology using normal behavioural means. Signs of hunger were also observed in many turtles and this is a significant welfare concern in itself, for in addition to nutritional deprivation, the hunger state promoted feeding frenzies and cannibalism (Fig. 7), which is a notable issue at the facility.

The CTF feeding policy, which involved sporadic introductions of food, additionally appeared to exacerbate feeding competition and co-occupant aggression. Feeding competition (which is highly significant in the overcrowded conditions at the CTF) is not a typical behaviour for free-living sea turtles. In the case of intensive farming situations, less competitive feeders and individuals weakened by injury, disease or existing malnutrition may 'lose-out' to stronger individuals, with potentially serious health and welfare consequences. Green sea turtles are typical grazers and require abundant food sources on which to casually browse. Food dosing is in conflict with typical sea turtle biology and behaviour. Feeding competition also serves to bring large powerful turtles together inviting contact abrasions, and other injuries from co-occupant bites and from forceful contact with housing walls and structures. The extremely common dorsal aspect neck lesions in the adult breeder population are an example of both a physical and a behavioural problem. These incidents also offer opportunities for the spread of infection from water to open wounds or from turtle to turtle. Reproductive stress 
was also a potential factor where male harassment of females in intensive conditions can result in both psychological stress and injury for individuals of both sexes.

Fundamental underlying causes for co-occupant aggression and cannibalism include stress, overcrowding, deficient and inappropriate environments, hunger and possibly also nutritional deficiencies (Fig. 11). The possibility and extent to which nutritional deficiencies may be relevant is yet to be determined.

The nature and severity of what are frequently observed injuries in the CTF turtles has profound welfare ramifications beyond the obvious. At one level, these injuries will be painful and expose afflicted animals to subsequent infection and disease and aid to attract cannibalism. Further, animals with massive flipper trauma where digits and even gross flipper loss is involved are simply less able to swim to avoid co-occupant and cannibalistic assaults. The psychological stress involved for these compromised and traumatised individuals is likely to add considerably to their existing levels of stress. Signs of understimulation, as represented in Tables 2 and 5, were grossly evident throughout the facility. Although the breeder lake is larger than other enclosures, boundary exploration (Fig. 12) was common or extremely common and constitutes search and escape behaviour that is causally-related to overly restrictive conditions (Warwick 1990). Apart from the adult breeder lake, which possessed an artificial beach for egg-laying, and the naturalistic lagoon which accommodated only a few small display turtles, none of the turtle enclosures possessed environmental enrichment features.

In nature, green turtles are largely solitary animals that occupy large spatial ranges, and diverse and stimulating environments. Important essential innate drive states and biological needs cannot be provided for in the highly limited captive

Fig. 12 Captivity-stress-related boundary exploration among the adult breeder population. Photo C Warwick

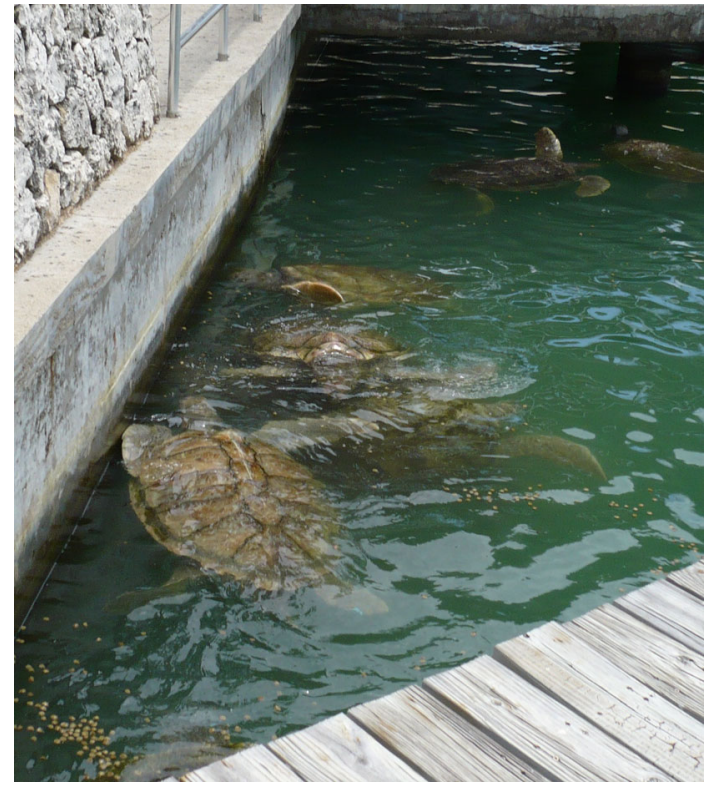


conditions of the CTF and these deficiencies probably importantly underline numerous problematic stress-related physical and behavioural manifestations.

Historically, public handling of turtles at the CTF was often unsupervised and arbitrary, and incidental handling abuses, including falls, were recorded (WSPA unpublished). Impact injuries from 'drops' may result in covert fractures and other harm and this presented an additional welfare concern. Turtle handling was supervised during the direct onsite inspection and it was noted that a revised policy has resulted in turtle handling being confined to holding the animals 'over water' for their protection. However, the majority of turtles were clearly stressed by the handling experience and manifested antipredator and escape behaviours (Gillingham 2004; Mellgren and Mann 2003; Smith and Salmon 2009).

Occasional acute stressors, while disturbing for animals, are not necessarily harmful experiences and physiological conditions can rapidly re-stabilise following an event (Guillette et al. 2004; Warwick 2004). However, this does not imply that arbitrarily subjecting the turtles to acute stressors is consistent with good animal care, and there exists the potential that repeated acute stress episodes may lead to compromised wound healing and pathology (French et al. 2005; Warwick 2004).

The contrast in behaviour that we observed between turtles in the general display enclosures and those in the relatively large and naturalistic lagoon was considerable, with turtles in the naturalistic lagoon showing no signs of captivity-stress, besides occasional boundary exploration, which probably emerges from the hard-wired behaviour for these animals to travel long distances and encounter novel environments.

It is also concerning that the farm holds numerous very large individuals of hawksbill turtles (Eretmochelys imbricata) and Kemp's ridley turtles (Lepidochelys kempii) as apparent long-term attractions in spatially extremely restrictive and understimulating enclosures. One mature specimen of the latter species possessed signs of both extensive physical injury and symptoms of microbial infection concomitant with poor animal welfare and husbandry.

\section{Conclusions}

We determined that acute and chronic issues of captivity-stress, including injuries, disease and behavioural problems, are regularly observable among turtles at the Cayman Turtle farm (CTF), and that these issues substantially relate to both the limitations of sea turtle adaptive plasticity in captivity and to historical and ongoing intensive turtle propagation and animal husbandry. Problems such as overt- and crypto-overcrowding, understimulating environments, and failures to meet all the physical, biological and innate behavioural needs of these animals are major factors affecting turtle welfare. We are unable to offer meaningful recommendations to remedy these welfare issues that would be consistent with the facility's current remit. First, the facility cannot replicate either the spatial scale or the environmental diversity of sea turtle habitat. Second, reptilian innate biological needs are incompatible with artificial, intensive, and understimulating captive conditions. Our assessments, based on direct onsite investigation, strongly corroborate our 
assessments based on the visual materials and reports provided by investigators from the World Society for the Protection of Animals, although it appears from our study that generally turtles in the display areas of the facility are in better condition than those situated in the main production areas. Finally, the CTF is located only a few hundred metres from regularly visited laying sites for wild turtles. Theoretically, there may be some risk of disease transmission and spread from captive to wild turtle populations via the release of potentially contaminated wastewater, which is regularly discharged from the facility, and further research of this potential threat to wild turtle populations may be warranted.

Open Access This article is distributed under the terms of the Creative Commons Attribution License which permits any use, distribution, and reproduction in any medium, provided the original author(s) and the source are credited.

\section{References}

Anon. (2012). 300 Green turtles die at Cayman Turtle Farm. Wildlife extra news. Available: http://www. wildlifeextra.com/go/news/cayman-turtle-farm.html\#cr. Accessed April 30, 2013.

Arena, P. C., \& Warwick, C. (2004). Miscellaneous factors affecting health and welfare. In C. Warwick, F. L. Frye, \& J. B. Murphy (Eds.), Health and welfare of captive reptiles (pp. 263-283). London and New York: Chapman \& Hall/Kluwer.

Ariel, E. (2011). Viruses in reptiles. Veterinary Research, 42(1), 100. doi:10.1186/1297-9716-42-100.

Balazs, G. H., Broderick, A. C., Godley, B. J., \& Work, T. M. (unpublished). Inspection of Cayman Turtle Farm. December 10-12, 2012, report to the Cayman Turtle Farm (Ltd.)

CTF FOI declaration to WSPA. (2012). Cayman Turtle farm Freedom of Information declaration to the World Society for the Protection of Animals

Curry, S. S., Brown, D. R., Gaskin, J. M., Jacobson, E. R., Ehrhart, L. M., Blahak, S., et al. (2000). Persistent infectivity of a disease-associated herpesvirus in green turtles after exposure to seawater. Journal of Wildlife Diseases, 36(4), 792-797.

French, S., Matt, K. S., \& Moore, M. C. (2005). The effects of stress on wound healing in male tree lizards (Urosaurus ornatus). General and Comparative Endocrinology, 145(2006), 128-132.

Frye, F. L. (1991). Biomedical and surgical aspects of captive reptile husbandry (2nd ed., Vol. 1). Malabar, FL: Krieger Publishing Co.

Gillingham, J. C. (2004). Normal behaviour. In C. Warwick, F. L. Frye, \& J. B. Murphy (Eds.), Health and welfare of captive reptiles (pp. 131-174). London and New York: Chapman \& Hall/Kluwer.

Glazebrook, J. S., \& Campbell, R. S. F. (1990). Survey of the diseases of marine turtles in northern Australia. I. Farmed turtles. Diseases of Aquatic Organisms, 9, 83-95.

Godley, B. J. (2002). Cayman Turtle farm: Consultancy report to DEFRA September 15, 2002, 23 pp.

Guillette, L. J., Jr, Cree, A., \& Rooney, A. A. (2004). In C. Warwick, F. L. Frye, \& J. B. Murphy (Eds.), Health and welfare of captive reptiles (pp. 32-81). London and New York: Chapman \& Hall/ Kluwer.

Haines, H. G., Rywlin, A., \& Rebell, G. (1974). A herpesvirus disease of farmed green turtles (Chelonia mydas) (pp 183-195). Proceedings of world mariculture. New York: Wiley Online Library.

Hoff, G. L., \& Hoff, D. M. (1984). Herpesviruses of reptiles. In G. L. Hoff, F. L. Frye, \& E. R. Jacobson (Eds.), Diseases of amphibians and reptiles (pp. 159-167). New York: Plenum Press.

Homer, B. L., Jacobson, E. R., Schumacher, J., \& Scherba, G. (1994). Chlamydiosis in mariculture-reared green sea turtles (Chelonia mydas). Veterinary Pathology, 31, 1-7.

Huchzermeyer, F. W. (2002). Diseases of farmed crocodiles and ostriches. Revue Scientifique et Technique (International Office of Epizootics), 21(2), 265-276.

Huchzermeyer, F. W. (2003). Crocodiles: Biology, husbandry and diseases. Oxon: CABI Publishing.

Losey, G. S., Balazs, G. H., \& Privitera, L. A. (1994). Cleaning symbiosis between the wrasse, Thalassoma duperrey, and the green turtle, Chelonia mydas. Copeia, 3, 684-690.

Mellgren, R. L., \& Mann, M. A. (2003). Habitat selection and antipredator behavior in three species of hatchling sea turtles. International Journal of Comparative Psychology, 16, 156-172. 
Norton, T. M. (2005a). Sea turtle critical care and emergency medicine. Jekyll Island: The Georgia Sea Turtle Center.

Norton, T. M. (2005b). Chelonian emergency and critical care. Seminars in Avian and Exotic Pet Medicine, 14(2), 106-130.

Pare, J. A., Sigler, L., Rosenthal, K. L., \& Mader, D. R. (2006). Microbiology: Fungal and bacterial diseases of reptiles. In D. R. Mader (Ed.), Reptile medicine and surgery (2nd ed., pp. 217-238). Philadelphia: Saunders/Elsevier.

Reiser, A. (2012). The case of the green turtle: An uncensored history of a conservation icon. Baltimore: John Hopkins University Press.

Ross, J. P. (1999). Ranching and captive breeding sea turtles: Evaluation as a conservation strategy. In: Eckert, K. L., Bjorndal, K. A., Abreu-Grobois, F. A., \& Donnelly, M. (Eds), Research and management techniques for the conservation of sea turtles (pp. 197-201). Washington DC: IUCN/ SSC Marine Turtle Specialist Group, Gland, Publication No 4.

Sazima, C., Grossman, A., \& Sazima, I. (2010). Turtle cleaners: Reef fishes foraging on epibionts of sea turtles in the tropical Southwestern Atlantic, with a summary of this association type. Neotropical Ichthyology, 8(1), 187-192. doi:10.1590/S1679-62252010005000003).

Smith, M. M., \& Salmon, M. (2009). A comparison between the habitat choices made by hatchling and Juvenile green turtles (Chelonia mydas) and Loggerheads (Caretta caretta). Marine Turtle Newsletter, 126, 9-13.

Warriss, P. D., Brown, S. N., \& Adams, S. J. M. (1994). Relationships between subjective and objective assessments of stress at slaughter and meat quality in pigs. Meat Science, 38, 329-340.

Warwick, C. (1990). Reptilian ethology in captivity: Observations of some problems and an evaluation of their aetiology. Applied Animal Behaviour Science, 26, 1-13.

Warwick, C. (2004). Psychological and behavioural principles and problems. In C. Warwick, F. L. Frye, \& J. B. Murphy (Eds.), Health and welfare of captive reptiles (pp. 205-238). London and New York: Chapman \& Hall/Kluwer.

Warwick, C., Arena, P. C., Lindley, S., Jessop, M., \& Steedman, C. (2013a). Assessing reptile welfare using behavioural criteria. In Practice, 35(3), 123-131. doi:10.1136/inp.f1197.

Warwick, C., Arena, P. C., \& Steedman, C. (2013b). Human health implications associated with farmed sea turtles. Journal of the Royal Society of Medicine Short Reports, 4, 8. doi:10.1177/ 2042533313475574.

Warwick, C., Lindley, S., \& Steedman, C. (2011a). How to handle pets: A guide to the complexities of enforcing animal welfare and disease control. Environmental Health News, 8, 18-19 (Chartered Institute for Environmental Health).

Warwick, C., Lindley, S., \& Steedman, C. (2011b). Signs of stress. Environmental Health News, 10, 21 (Chartered Institute for Environmental Health).

WSPA unpublished report. World Society for the Protection of Animals, London. 